Original research article

\title{
Job satisfaction of general nurses in standard and intensive care units: "The nurse is a jack-of-all-trades!"
}

\author{
Alena Glajchová ${ }^{*}$, Eva Hlaváčková ${ }^{2}$, Jana Holá ${ }^{2}$, Markéta Moravcová ${ }^{3}$ \\ ${ }^{1}$ University of West Bohemia, Faculty of Philosophy and Arts, Department of Sociology, Pilsen, Czech Republic \\ ${ }^{2}$ University of Pardubice, Faculty of Health Studies, Department of Clinical Subspecialities, Pardubice, Czech Republic \\ ${ }^{3}$ University of Pardubice, Faculty of Health Studies, Department of Midwifery and Health and Social Work, Pardubice, Czech Republic
}

\begin{abstract}
New trends in providing healthcare are dynamically changing the field and increasing demands on healthcare staff. The adequate capacity and training of healthcare staff is considered an essential measure of the quality of the provided care. The shortage of health personnel is becoming one of the most pressing issues and challenges facing both the health system and society as a whole. The aim of this text is to shed light on how general nurses perceive their profession and what influences their level of job satisfaction. To this end, qualitative research was conducted and the method of in-depth interviews was used to determine the experiences of general nurses (working in standard and intensive care units) in their profession. The general nurses evaluated the issues of their work through aspects related mainly to management, teamwork, working conditions, competency, adaptation process, prestige and respect. There is an interplay between the various factors that affect the subjectivity of general nurses in different situations and with different intensities. General nurses perceive higher financial remuneration as a motivation, but not as a major predictor of their job satisfaction. Nurses interpreted the key factors for job satisfaction to be communication and collaboration.
\end{abstract}

Keywords: Communication; General nurses; Job satisfaction; Management; Shortage of nurses

\section{Introduction}

The health care system has faced many changes over the last three decades. Contemporary trends in providing healthcare mean increasing demands on healthcare staff and changing working conditions in which their daily performance of tasks takes place. Part of this everyday reality is not only the professional performance itself, but also other aspects and regulations related to the running of the organisation and focusing on providing the best quality care. Today, a fundamental measure of the quality of care is sufficient capacity and education of healthcare staff.

The shortage of health personnel is becoming one of the most pressing issues and challenges facing both the health system and society as a whole. According to data from the Institute of Health Information and Statistics (IHIS), there are 2,000 fewer general nurses in hospitals than in 2010. The data for the year 2018 shows that the trend in acute care and outpatient care is different from other inpatient care. While acute care and outpatient care have been affected by a yearon-year decline in general nurses, there has been an increase in general nurses in inpatient care over the same period (IHIS, 2018). Thus we cannot think of this issue as a phenomenon that affects the entire health sector to the same extent; the data shows that staffing capacity varies depending on the type of care provided. Shortage of health personnel is an important indicator of job satisfaction/dissatisfaction, leading to the departure of health personnel from the health sector.

The concept of job satisfaction is very complex, as evidenced not only by the many definitions used, but also by its wide application in research in psychology, sociology, education and organizational behaviour (Al Maqbali, 2015). However, due to its wide applicability, its use extends to many other scientific disciplines. The concept of job satisfaction is considered a crucial indicator that communicates the extent to which employees like their jobs (satisfaction) and stay in their positions, or the extent to which employees dislike their jobs (dissatisfaction), which may lead to their departure (Alameddine et al., 2017). The relevance of this concept is particularly apparent when the negative effects of job dissatisfaction are discussed (Masum et al., 2016), or when there is the need for staffing healthcare facilities in the context of an ageing population (Lu et al., 2019).

According to Aziri (2011, p. 78), job satisfaction can be defined as "the set of feelings and opinions that people have about their current job". This can include general attitudes towards work, but also specific aspects such as working condi-

\footnotetext{
* Corresponding author: Alena Glajchová, University of West Bohemia, Faculty of Philosophy and Arts, Department of Sociology, Univerzitní 8, 30614 Pilsen, Czech Republic; e-mail: alenag@kss.zcu.cz http://doi.org/10.32725/kont.2021.032 
tions or pay (Lu et al., 2019). This attitude is thus influenced by the extent to which the job fulfils the material and psychological needs and expectations of the individual (Aziri, 2011).

Job satisfaction and the correlation between job satisfaction and the retention of general nurses have become the subject of a lot of research both abroad and in the Czech Republic. Job satisfaction is shaped by various aspects of the organizational culture of healthcare facilities (Aiken et al., 2013). The essential factors include working conditions, financial remuneration, management, workplace relationships, or personal growth (Lee et al., 2017). Current studies focus on variability in the job satisfaction levels of general nurses in different countries, which is explained by different settings of particular health care systems and also by whether the country is or is not a member of the European Union (Aiken et al., 2013; Spevan et al., 2020). Socio-demographic characteristics are not neglected either. The age of nurses (and thus also their age when they started their professional role) appears to be crucial, highlighting the importance of the adaptation process. The role of the supervisor and their support is a significant factor influencing a general nurse's decision to stay or leave their position (Masum et al., 2016; Lee et al., 2017).

In the Czech Republic, the issue of job satisfaction of general nurses has been the subject of many studies. For example, Ivanová et al. (2012) claim that most nurses are satisfied (91.6\%), but more than a third (35\%) of them are ready to leave. Based on their own research, they provide an overview of the work environment factors according to F. Herzberg's theory of motivation. The factors were first ranked by the general nurses according to value preferences, and then according to their perceived fulfilment from the employer. Ivanová and her team (2012) emphasise that salary is the most important factor for job satisfaction of general nurses, but at the same time the one that is the least fulfilled.

Research conducted so far shows that financial remuneration is the most important factor influencing general nurses' satisfaction. However, it is also linked to other aspects such as working conditions, job security, patient care or interpersonal relationships (Bártlová and Hajduchová, 2010; Nakládalová et al., 2011). Haroková and Gurková (2013) researched studies conducted in different countries and pointed out that it is an interplay between multiple factors that results in the positive (satisfaction) or negative (dissatisfaction) attitude of a particular employee towards his or her work.

In this text, we aim to provide an overview of how general nurses perceive their profession and to clarify what influences their level of job satisfaction. Most of the existing research on this topic in the Czech environment is based on a quantitative methodology. The findings presented in this text come from a qualitative pre-research, which is part of a broader study mapping the factors influencing general nurses' lack of capacity and competency. The use of qualitative interviews enables us to gain a deeper insight into the experiences of general nurses, and to identify factors influencing levels of job satisfaction, or highlight the interconnectedness between these factors that may fundamentally affect the nurses' motivation and their decision to stay or leave their facility/profession.

\section{Materials and methods}

The data presented in the text comes from a qualitative pre-research that was conducted as part of a larger research project focused on general nurses' job satisfaction and competencies. The intention of this research was to gain a deeper understand- ing of the issue, and to identify themes and sub-themes relating to general nurses' satisfaction which then became the basis for the construction of the questionnaire and survey. The criteria chosen by the researchers for the selection of the general nurse sample were: length of experience, type of department according to the care provided, managerial position, and leaving the profession. The researchers conducted in-depth interviews with four groups of informants:

1) general nurses after the adaptation process with less than 2 years of experience ( 6 interviews, 5 women and 1 man);

2) general nurses with more than 2 years of experience (8 interviews, 8 women);

3) general nurses in managerial positions (9 interviews, 8 women and 1 man);

4) general nurses who have left the profession in an acute care hospital (8 interviews, 7 women and 1 man).

The informants were selected using the snowball sampling method. The researchers conducted the interviews upon prior arrangement and with the consent of the particular general nurse. The interviews lasted 45 to 90 minutes. The researchers stopped data collection when themes became repetitive.

The interviews conducted were always recorded with the consent of the informant, and then transcribed verbatim. Interview data were subjected to thematic analysis using ATLAS.ti software in the following steps: repeated readings; open coding including analytical notes; identification of themes and subthemes (Hendl, 2005). The main themes interpreted in the text emerged from the analysis of the interviews as key in the formation of general nurses' satisfaction mechanisms. Providing interview extracts ensures the credibility of the interpreted themes and the relationships between them.

All participants were informed about the purpose of the research, including the principle of anonymity. All data, including information relating to hospital facilities, have been anonymised, and the names given in the text are fictitious. The research followed the ethical principles for conducting research according to the American Sociological Association's Code of Ethics (ASA, 2018).

\section{Results}

\section{Management and relations with superiors}

The general nurses talked about their experiences in daily practice and their perception of their profession. Their evaluations also reflected certain aspects of their work that affect their level of satisfaction. Most of the general nurses identified management and relationships with supervisors as key aspects that are essential for the smooth running of the ward. For example, Marta (R1/4) considers a functioning relationship between the head doctor and the head nurse as primary, as it further influences the setting of rules and relationships within the whole department.

"I think the management of the ward is important. So if the head doctor and the head nurse make arrangements, and doctors have their rules set, everything works just fine. And if there is no arrangement, it doesn't work. And everything's going to fall on nurses. (...) They should just have those information meetings, say what's needed or some kind of plan" (Marta, R1/4).

Effective communication is a part of management; which was also perceived by Marta. In her narration, she emphasizes the importance of communication with superiors and sharing experiences - something which she feels is missing in her job. According to head nurse Jana (R2/3) the most important thing 
is "to have communication channels working", across all professions. Almost all informants shared this view. It is clear from their statements that they perceive "communication channels" as fundamental in terms of the management of a given department - and these also seem to be one of the main predictors of job satisfaction. For example, disagreements with the head nurse were the main reason for general nurse Markéta (R3/1) leaving the hospital's acute care unit, although her decision to leave was also caused by other factors (e.g. shift work and overtime).

\section{Role of the ward nurse}

Many informants highlighted the specific role of the ward nurse as central to the running of the ward and establishing collaboration with doctors. Although collaboration between doctors and general nurses is addressed in the next section of the text (teamwork), the informants' interpretation of the importance of the role of the ward nurse and the expectations associated with this also ought to be highlighted here.

For instance, head nurse Jana (R2/3) claimed that is important for the cooperation with the doctors "how the ward is run by the ward nurse, what kind of atmosphere she brings to it, how she communicates with the doctors, because then she's a kind of mirror for how the other nurses will treat the doctors". Jana (R2/3) admitted that even if the instruction comes from the head nurse, what matters is how the ward nurse communicates those instructions to the other medical staff and whether there is any modification to those instructions.

In terms of expectations, Jana (R2/3) felt that the ward nurse should primarily have management skills. Marta (R1/4) believed that the ward nurse should "make it easier for a nurse to be with a patient more". For example, helping with administration, patient admissions or securing aids. Expectations of the role of the ward nurse were always related to her commitment and management skills. However, it should be noted, as Jiří (R3/3) in a managerial position also argued, that the importance of the head nurses' role in the communication chain cannot be ignored. Perceived support, standing up for their staff and humanness, both from the ward nurse and the head nurse, also play a role in the satisfaction of general nurses. In her narration nurse Hanka (R8/2) defined the humanness of a superior as "being closer to us" and not approaching staff with a distant, condescending attitude.

\section{Teamwork}

The issue of teamwork, considered to be the foundation of organizing health care, is currently receiving increased attention. The relationship between general nurses and doctors has undoubtedly changed as a result of the professionalisation of general nurses and the increase in their competencies, raising the question of equal partnership and the nature of collaboration.

Some informants perceived that collaboration between general nurses and doctors entails problematic communication and a number of difficulties. Hanka (R8/2) talked about a kind of automated "reliance" of doctors on nurses as a negative aspect of their attitude towards nurses i.e. nurses often have to perform activities that are within the competency of doctors. However, she also reflects upon the positive experience of their cooperation, which she generally considers most important for teamwork:

"The doctor comes and asks: What do you think about it? Do you agree with it? And that's totally, that's like unbelievable, that they don't take you as a servant who's got to do what's written on a paper, they take you as an equal just like a partner" (Hanka, R8/2).
Hanka (R8/2) pointed out the contradiction in the attitude of doctors towards nurses, where on the one hand doctors rely on nurses to manage the doctor's duties, and thus nurses exceed their competencies. On the other hand, she mentions a shift towards the perception of nurses as partners. "It's always about the team and the collaboration, it's not about anything else," argued manager Monika (R1/3), reflecting upon a certain shift in the nature of the relationship across time. However, her reflection was negative in comparison to Hanka's (R8/2), as she felt that relationships are currently "worse" due to a generational shift, a "disappearing" hierarchy between professions, and a loss of respect.

On the other hand, some general nurses spoke of a "present" hierarchy, which again significantly affected teamwork and consequently the nurses' level of job satisfaction. In fact, according to Edita (R7/1), younger general nurses who have newly arrived are disadvantaged by their position because older nurses make it clear that they are "above" them. This superiority of the older and more experienced nurses may reduce the satisfaction level of the newcomers and influence their decision to leave the position. Adam (R4/1) discussed the impact of hierarchical structure on his decision to leave. From his point of view, the lack of cooperation between doctors and general nurses can have a negative impact on the credibility of general nurses and lead to a threat to their position and professional performance - which he could not accept:

"You can't do anything without a doctor, and that's the problem. The doctor should support you. Often we call the doctor, but he refuses to come. But everyone trusts a doctor more than two nurses. And then he [note: the doctor] lets us down, saying he didn't know anything" (Adam, R4/1).

From the informants' accounts a contradiction can be identified in relation to the issue of a "disappearing" or "present" hierarchy, particularly regarding the impact of the specialisation of particular activities on the relationship between nurses and doctors and teamwork in general. For example, Katerina (R6/2), argued: "As soon as you don't work in a good team, it reflects in the work, and even in if you want to go to work at all." Teamwork requires constant communication because in a team "everyone depends on each other and needs each other".

\section{Working conditions}

General nurses also talked about working conditions. They most frequently mentioned the psychological demands of the profession, excessive administration, shortage of staff and other aspects of the particular environment in which they practise or had practised their profession.

"All the time there are higher demands on the profession. The medical documentation, which is incredibly time consuming and the patient comes last. (...) You work 12 hours straight, or 13, you're tired, overworked, and it's terribly demanding, especially when you have kids at home. It's just not possible" (Markéta, R3/1).

Markéta (R3/1) talked about her departure, which can be understood as a result of multiple factors. In addition to disagreements with the head nurse, her decision was largely due to the demands of the profession, particularly as a result of shift work and parenthood, as was the case for most of the other interviewed nurses who left the hospital. In fact, for seven of them, shift work was incompatible with their parental role. The inability to work on another ward or part-time had forced them to seek another health facility or a completely different profession.

"For me, as a mother, the priority is to take my kids to daycare in the morning, and pick them up, and be with them, not to get 
home after a 12-hour shift, and then be with them just for a while" (Markéta, R3/1).

Markéta (R3/1) left the hospital as she "wanted something calmer, without so much adrenaline". Nevertheless, the profession of a general nurse remained "top spot" for her, and she now works at the Alzheimer Centre, albeit under completely different working conditions.

The demanding nature of the profession can also be affected by a high number and turnover of patients. "We heal the patient and send him away," argued Adam (R4/1), who was highly dissatisfied with the working conditions and compared the hospital to a "factory". While talking about leaving her job, Edita (R7/1) repeatedly mentioned the difficulty of caring for a large number of patients, but also the patient turnover or frequent dying she witnessed in the ward.

The inability to care for patients due to lack of time and staff was criticized not only by the "departed" nurses, but also by other informants. These working conditions, which make general nurses dissatisfied, can significantly affect not only the increasing number of complaints from patients and their families, but also the quality of care or the impersonal approach in patient care.

"Well, when I was in the internal medicine ward I was just surprised that no one seemed to notice (...) Why are there these complaints when there are so many people and so few staff. (...) So it's reflected in the care. That bothered me" (Iva, R2/2).

Iva (R2/2) was so dissatisfied with the working conditions that she decided to move to another ward, which made her happier as she "always has patients in sight". Marta (R1/4) too emphasised that the type of care provided varies with respect to the type of ward, saying: "In the ICU you have time to do it [note: provide care], there it's like a procedure (...) and the patient is really clean, there are no bedsores and in the standard care unit you just can't do it." Iva (R2/2) often found herself in a precarious situation in the standard care unit, as the doctor was not always "available" and therefore she had to rely on herself in some situations. Moving from the standard care unit to the intensive care unit gave Iva (R2/2) the security and opportunity to "be" with her patients.

The analysis shows that the environment has a major influence on whether general nurse competencies are exceeded or respected, both in terms of lower and higher (medical, specialised) competencies. According to Iva (R2/2), in the standard care unit, there was often an overstepping of the general nurse's competencies. She explained the situation simply: "The doctors were not keeping up, so it was left to us." On the other hand, in the intensive care unit, Iva (R2/2) encountered officially assigned competencies that were strictly observed by everyone.

\section{Competency and the adaptation process}

Interestingly, most of the general nurses did not explicitly discuss competency as a reason for their reduced satisfaction levels. However, if they mentioned non-compliance, such situations made them concerned. For example, Marta (R1/4) criticized the current system of education for health care staff, which she felt introduces a certain chaos and ignorance of the competencies of different professions into practice. She spoke of crossing boundaries (of competencies) as a daily experience that resulted from staff shortages. She stressed that "everybody does everything" - it means that competencies are in practice overstepped in both directions, by the general nurses as well as the lower nursing staff.

Most often, general nurses associated the overstepping of competencies positively, as it is usually a necessary and ben- eficial step. Tomáš (R4/4), with 2.5 months of experience, illustrated such a situation in terms of the urgency of the case.

"We all know what our competencies are, what we have to do. (...) Things have happened before, but it was like, I don't know, in the acute admissions, a lady just wasn't eating, she had a bad glycaemia, so the doctor said, look, go, please, put in $10 \%$ glucose, eight units of Actrapid and let it drip. So of course I'm not going to wait for her to fill out the admission form, the paperwork, before she writes it down, and I'm going to administer it right away, right?" (Tomáš, R4/4).

For Tomáš (R4/4), the priority is to ensure patient care, so the urgency of the condition is, in his opinion, a clear reason for overstepping his competencies. Blanka (R1/1), who has completely left the health sector, mentioned situations requiring the need to act beyond competency, especially in the absence of a doctor. However, she added that there are also situations where a doctor is present and delegates his/her competencies to a general nurse.

"Or the paperwork. That's another thing a nurse often does instead of a doctor. There's more to it, of course. There's a lot of things that the doctor just leaves to the nurse. He'll say from the table 'hey redress this, put this here and that in there' and that's it. But I've never really questioned that. I didn't take it that way. It's just always been a kind of division of labour. Yeah, you know, some things you'd rather do than others, but that's with everything. (...) And we've always helped each other and we always do" (Blanka, R1/1).

Blanka (R1/1) never questioned these situations, she took "doing the doctor's job" as part of the division of labour at that time in the outpatient surgery. In her interview, she went on to talk about helping out and shift work on the inpatient department, where the crossing of competencies is even "commonplace". Similarly, Verra (R6/1) stated: "Sure, they are overstepped all the time. Both up and down. Multiple times a day. It comes naturally to me and I do it naturally. When I know I can do it, I do it. If I'm not sure, I don't do it." It could be said that this is a daily practice that requires "knowledge and then you dare to do it" (Věra, R6/1). Thus, exceeding competencies is not always explicitly perceived as a cause of dissatisfaction, but it is evident that it increases the demanding nature of professional performance and consequently decreases the level of job satisfaction.

The analysis reveals a similar interdependence of factors in the case of the adaptation process, the occurrence and length of which varies with respect to the specifics of the particular department, such as staff shortages, management and overall departmental setup. Kateřina (R6/2) stated that the shortage of staff causes the absence of a mentor and consequently influences the "retention" of new staff.

"And I think it's just a shame, we have a new person coming in that we're trying to train, and even the station nurse doesn't have time to actually train the new colleague, and they [note: new colleagues] leave after a month or so because they're overwhelmed with the job because they can't handle it" (Kateřina, R6/2).

Kateřina (R6/2) calls this a "vicious circle". Similarly, Marta (R1/4), who did not even "notice" her adaptation process, says: "I kind of fell into it (...) they just said, do this and that." General nurses interpret their own adaptation process as "being thrown into the water" or as a "trial period". This "throwing into the water" is more characteristic of the standard care unit, which was perceived by the nurses themselves as less prestigious and the most challenging with regard to staff capacity and working conditions.

The testimonies of general nurses show that the importance and length of the adaptation process increase with the higher attractiveness of the ward (the intensive care unit is 
for instance perceived as more attractive workplace than the standard care unit). Manager Jana (R2/3) started her career on a standard care unit where "learning just didn't happen". After four years, Jana (R2/3) moved to an intensive care unit where learning was emphasised. She even educated herself to make the adaptation as easy as possible for her. Nevertheless, she says that "back then it was not customary to lead someone by the hand and show them everything". As for her promotion to the post of head nurse, she has already gone through a several-month adaptation process with her mentor, a former head nurse.

According to the manager Monika (R1/3), it is essential to "have a good trainer" who decides how the adaptation process is set up and how it is carried out. Monika (R1/3) spoke of an experience where she had seen a trainer "bullying" a new nurse for something she did not know, and was too strict. In her testimony, she described the ideal trainer with an emphasis on the qualities that he or she ought to have.

"It should be someone who respects all the procedures, standards, guidelines, etc. and tries to really do it honestly. (...) She needs to be a little bit communication savvy and just kind of empathetic and be clear about the goal" (Monika, R1/3).

It is the job of the head or station nurse to choose the right trainer. The adaptation process is therefore closely linked to the quality and capacity of the staff and the management that sets it up. At the same time, its diversity introduces some confusion about what the adaptation process is and what its length is. As Monika (R1/3) added, the adaptation process should not just be a "piece of paper". The bottom line is that the form of the adaptation process shapes the experience and satisfaction level of the general nurses, and their decision to stay.

\section{Prestige and respect}

In the interviews, the general nurses reflected on their role and the respect they felt towards it, and, from the analysis, this emerged as a specific theme affecting their daily experience. All the informants perceived their profession as important and the majority of them interpreted it as a "mission". Zuzana $(\mathrm{R} 1 / 2)$ even expressed pride in being a nurse. Yet, many of them talk about being undervalued.

Edita (R7/1) stressed that although nurses have higher competencies, they are morally and financially undervalued. Some of them talked about the lack of respect and appreciation from their superiors, in different situations and forms, such as "not standing up for them" and not being trusted when there is a problem or complaint. Even more emphasis was placed on the public perception of the role of the general nurse. Many nurses are of the opinion that although society values the profession, the public "image" of the general nurse is inadequate. They see the cause of devalued view of the nursing profession in nurses' portrayal in the media.

According to the manager Monika (R1/3), the prestige of general nurses has been steadily declining and contradicts the importance of the profession. She stresses that the general nurse is the one "who does a big part of the care", but this is overlooked even within the organisation itself.

"Nobody takes us seriously and doctors just can't do anything without us. (...) Doctors just have to keep proper medical records, and everything else falls on nurses who do the work and know everything" (Monika R1/3).

Marcela (R7/3) gave a similar testimony, as according to her, the patient comes to the hospital because of the need for nursing care, i.e. nurses. However, the perception of society is that everyone needs a doctor. The perceived decreasing prestige and respect is thus closely related to the hierarchy, within which the profession of general nurse is placed on a lower rung compared to the medical profession. Although this is not a factor that directly causes nurses to leave hospitals, the perception of their own profession as inferior and lacking in prestige makes nurses less satisfied.

\section{Discussion}

\section{Job satisfaction: what is a predictor?}

The job satisfaction of general nurses has been addressed by a number of foreign and Czech authors (Alameddine et al., 2017; Ball et al., 2017; Haroková and Gurková, 2013). The level of job satisfaction emerges as a key predictor of general nurses' retention in their professional role (Gurková et al., 2013). It also influences the running of the whole department and its climate. However, to provide a list of individual factors according to their importance is misleading and misrepresentative, especially if these are predefined categories. Analysis of qualitative interviews with general nurses reveals a complex picture of satisfaction, whereby the degree of satisfaction should be understood as the result of various intersecting factors, which may be individual, structural or contextual in nature (Hrešanová and Glajchová, 2018).

In terms of the most influential and problematic factors, relationships with management and teamwork can be identified as playing a very important role in motivating retention or, conversely, departure (Haroková and Gurková, 2013). Some informants often stressed "it's about communication". Effective communication is a central element of teamwork and should be part of the strategy of all managers. This also supports the perception of general nurses - who see the manager as a key person in relation to the practice of the profession. Managerial communication skills can contribute significantly to increasing the satisfaction of general nurses and reducing their turnover (Holá et al., 2020). However, in addition to management, general nurses also attached importance to other circumstances and factors that motivated them, increased their satisfaction, but also caused some of them to leave.

\section{Why did they leave? Education as a protective factor}

Despite the relatively significant number of studies looking at job satisfaction, research focusing on motivations for leaving an organisation or occupation is absent. According to Simon et al. (2010), variables related to personal reasons and family life are more likely to motivate professional departure.

Conversely, motivations to leave an organisation are linked to contextual factors. However, in our research, the accounts of the general nurses in our research who had left the organisation, suggest that the two types of departure cannot be clearly distinguished.

An expected answer to the question "Why did they leave?" is often the transition to motherhood. For several nurses, motherhood became a turning point that made them leave after a long consideration of all the advantages and disadvantages of their profession. The demanding nature of the profession increased many times over with their motherhood. Women were exposed to more stress and were forced to find strategies to balance childcare (family) and employment, especially in the case of shift work (Firmin and Pathammavong, 2012). Although some of the general nurses in the research sample had left the hospitals, they rarely gave up their profession (only one of the informants left the profession completely). Their departure was in pursuit of a calmer, less chaotic working environment, and was motivated by factors such as the need for 
self-fulfilment, learning, as well as poor relationships in the original workplace. The low level of job satisfaction of these general nurses led them to choose a different health or social service facility that better suited the time demands and family-work balance when they returned to the labour market.

On the other hand, it is necessary to consider motivators that balance negative emotions and dissatisfaction factors. One of them can be identified as (lifelong) education (Atefi et al., 2014), which can make general nurses feel self-actualization, orientation in "new things" and "moving on". For example, for Eva (R3/4), "knowing more" was an advantage, a specialisation that ultimately increased not only her job satisfaction but also the quality of care provided. The importance of lifelong learning for the retention of general nurses was highlighted by Renata (R9/1), who left the ward where "everything had come to a standstill". Such stagnation was particularly felt by nurses in standard care units with high staff turnover. This fact raises an appeal to employers to focus more on the education of non-medical staff and to set it logically in relation to the competencies and performance appraisal of general nurses. Thus the importance of lifelong learning should not be neglected, as the aforementioned self-actualization reduces the likelihood of attrition, increases job satisfaction, and influences the general nurse's identification with the organization (organizational commitment) (Lu et al., 2019).

Moreover, education can be seen as a mediator of the relationship between the adaptation process and job satisfaction levels. The importance of the adaptation process is associated with the changing healthcare environment for the newly arrived general nurse, most commonly the transition from an academic setting to a structured and highly dynamic environment. Although the adaptation process is formally anchored by the methodological instruction of the Ministry of Health of the Czech Republic from the year 2009 (MoH CR, 2009), its disparities and ambiguity give rise to contradictory perceptions. Some general nurses just accepted being "thrown into the water" with resignation and did not question the absence of a supervisor or trainer. On the contrary, many informants perceived such a course of adaptation as part of the routine. However, other nurses saw the absence of a quality supervisor as a risk that could create a conflict between expectations and reality in the newly arrived nurses that could then result in their subsequent departure (Lee et al., 2017). This transition can be stressful and frustrating (Duchscher, 2009), but also motivating if educational opportunities are available (Atefi et al., 2014). For this reason, it is important to understand how adaptation takes place and to respond to issues that may lead to the departure of nurses who were initially motivated.

\section{Conceptualizing the ideal nurse or versatility in the main role}

The analysis of the interviews with general nurses also revealed interesting findings regarding the conceptualisation of the socalled ideal nurse. The informants reflected on what the ideal nurse should be, and what he or she should be able to do. According to Martha (R1/4), a nurse "should be empathetic, calm, heal that person mentally and not be stressed out flying around the ward". Therefore, not only personality characteristics but also work organisation and education seem to be crucial, as they influence how a nurse affects patients and whether he or she is "good". Monika (R1/3) argued that to be a "good" nurse, she needs to keep herself fit, acquire new procedures and educate herself. However, these are not the only requirements for a "good nurse". In the interview, she went on to list qualities such as professionalism and communication skills, not only with patients but also with co-workers.

From the above, it is clear that the ideal nurse represents a union of someone who is a good nurse in terms of virtue ethics and someone who does the right things with an emphasis on nursing practice (Smith and Godfrey, 2002). These requirements and expectations relating to the performance of general nurses make them a kind of universal worker. As Eva (R3/4) emphasised in her narration, "The nurse is a jack-of-alltrades." The versatility of general nurses refers to the setting of individual workplaces and competencies. Indeed, as Eva (R3/4) added, "surprisingly the nurse does a lot of things that she is not normally competent in". The notion of the general nurse as a universal worker, as discussed by the informants, represents the demanding nature of the profession and the lack of adherence to competencies. The unclear competencies of health personnel and their overstepping of these competencies can be seen as a cause not only of difficult working conditions, but above all of a general shortage of personnel at the societal level. Edita (R7/1), who left the hospital environment, succinctly summed up the performance of the general nurse profession: "Exhaust your nurse!"

\section{Conclusions}

This text aimed to present how general nurses perceive their profession, and to explain what influences the level of job satisfaction based on general nurses' evaluation and experience from their daily practice.

The analysis of the interviews shows that aspects related to management and teamwork, working conditions, competencies and adaptation process, prestige and respect have a major impact on the level of satisfaction or dissatisfaction.

The study highlights the complexity of job satisfaction and the importance of individual factors, which should not be neglected, but rather assessed and addressed by management in the context of particular health care workplace settings. However, the possible departure of general nurses who have already been working for several years should not be ignored either. As evidenced by the informants' accounts, this can be supported by a number of factors. We would like to point out here a certain loop in the area of competencies, where the setting of working conditions and the organisation of work lead to overstepping these competencies. Although not always perceived negatively, this overstepping undoubtedly increases the demands placed on healthcare staff and the risk of leaving. This issue should be taken into account not only by management, but also by health and education policies, as there is an ever-increasing need to ensure sufficient staff capacity in the light of demographic trends.

The findings presented in the text cannot be generalised to the whole population of general nurses, but they reveal significant interdependence between all aspects of the factors. Moreover, the use of mixed-methods research appears to be an appropriate research design, as the qualitative methodology allows for many interrelationships and context-sensitive factors to be captured, thus supplementing the findings from the quantitative studies conducted so far. Also, the concept of intersectionality can be a useful tool for future research to analyse job satisfaction factors and to understand this complex phenomenon. 


\section{Funding}

This text was supported by the project "Competent Nurse for the 21st century: Analysis, and Proposal for Optimizing the Education and Performance of the General Nursing Profession" (Technology Agency of the Czech Republic, Grant No. TL01000094.).

\section{Ethical aspects and conflict of interests}

The authors have no conflict of interests to declare.

\section{Pracovní spokojenost všeobecných sester na oddělení standardní a intenzivní péče: „Ta sestra je pro všechno!“}

\section{Souhrn}

Nové trendy v oblasti poskytování zdravotní péče činí jeho prostředí dynamickým s rostoucími požadavky na zdravotnický personál. Za zásadní měřítko kvality poskytované péče je považována dostatečná kapacita a odborná vzdělanost zdravotnického personálu. Právě nedostatek zdravotnického personálu se stává v současné době jedním z palčivých témat a výzvou, jíž zdravotnický systém a celá společnost čelí. Cílem textu je objasnit, jak všeobecné sestry vnímají svoji profesi a co ovlivňuje míru jejich pracovní spokojenosti. Byl proveden kvalitativní výzkum. Metodou hloubkových rozhovorů byly zjištovány zkušenosti všeobecných sester s výkonem povolání, které působily na oddělení standardní a intenzivní péče. Všeobecné sestry hodnotí problematičnost své práce skrze aspekty vztahující se zejména k managementu, týmové spolupráci, pracovním podmínkám, kompetencím a adaptačnímu procesu či k prestiži a úctě. Dochází ke vzájemnému prolínání se jednotlivých faktorů, které působí na subjektivitu všeobecných sester $\mathrm{v}$ různých situacích a v odlišné intenzitě. Všeobecné sestry vnímají vyšší finanční ohodnocení jako motivaci, nikoliv jako zásadní prediktor jejich pracovní spokojenosti. „Klíč“ ke spokojenému výkonu povolání byl sestrami interpretován převážně skrze komunikaci a spolupráci např́íč všemi profesemi.

Klíčová slova: komunikace; management; nedostatek sester; pracovní spokojenost; všeobecné sestry

\section{References}

1. Aiken LH, Sloane DM, Bruyneel L, Van Den Heede K, Sermeus W (2013). Nurses' reports of working conditions and hospital quality of care in 12 countries in Europe. Int J Nurs Stud 50(2): 143-153. DOI: 10.1016/j.ijnurstu.2012.11.009.

2. Al Maqbali MA (2015). Factors that influence nurses' job satisfaction: a literature review. Nurs Manag (Harrow) 22(2): 30-37. DOI: 10.7748/nm.22.2.30.e1297.

3. Alameddine M, Bauer MJ, Richter M, Sousa-Poza A (2017). The paradox of falling job satisfaction with rising job stickiness in the German nursing workforce between 1990 and 2013. Hum Resour Health 15(1): 55. DOI: 10.1186/s12960-017-0228-x.

4. ASA - American Sociological Association (2018). Code of ethics. Page last reviewed. [online] [cit. 2020-12-20]. Available from: http://www.asanet.org/sites/default/files/asa_code_of_ethicsjune2018.pdf

5. Atefi N, Abdullah KL, Wong LP, Mazlom R (2014). Factors influencing registered nurses perception of their overall job satisfaction: a qualitative study. Int Nurs Rev 61(3): 352-360. DOI: 10.1111/inr.12112.

6. Aziri B (2011). Job satisfaction: a literature review. Manag Res Pract 3(4): 77-86.

7. Ball J, Day T, Murrells T, Dall'Ora C, Rafferty AM, Griffiths P, Maben J (2017). Cross-sectional examination of the association between shift length and hospital nurses job satisfaction and nurse reported quality measures. BMC Nurs 16: 26. DOI: 10.1186/s12912-017-0221-7.

8. Bártlová $S$, Hajduchová $H$ (2010). Psychofyzická zátěž a příčiny fluktuace sester. Zdravotnictví v České republice 13(3): 110-115.

9. Duchscher JEB (2009). Transition shock: The initial stage of role adaptation for newly graduated registered nurses. J Adv Nurs 65(5): 1103-1113. DOI: 10.1111/j.1365-2648.2008.04898.x.

10. Firmin MW, Pathammavong MB (2012). A qualitative study of mothers who work full-time as hospital floor nurses. Int J Adv Nurs Stud 1(2): 125-149.
11. Gurková E, Soósová MS, Haroková $S$, Žiaková K, Šerfelová $R$, Zamboriová M (2013). Job satisfaction and leaving intentions of Slovak and Czech nurses. Int Nurs Rev 60(1): 112-121. DOI: 10.1111/j.1466-7657.2012.01030.x.

12. Haroková S, Gurková E (2013). Pracovní spokojenost jako prediktor setrvání sester na pracovišti - literární přehled. Ošetřovatelství a porodní asistence 4(2): 573-582.

13. Hendl J (2005). Kvalitativní výzkum: Základní metody a aplikace. Praha: Portál.

14. Holá J, Moravcová M, Hlaváčková E (2020). Communication competency: The topic of lifelong learning for nurse managers in hospitals. Kontakt 22(1): 33-39. DOI: 10.32725/ kont.2019.053.

15. Hrešanová E, Glajchová A (2018). Staré a cizí: Zranitelnost a intersekcionalita ve zdravotní péči. Gender a Výzkum 19(2): 75-101. DOI: 10.13060/25706578.2018.19.2.427.

16. IHIS [Institute of Health Information and Statistics of the Czech Republic] (2018). Zdravotnictví ČR: Personální kapacity a odměňování. [online] [cit. 2021-01-15]. Available from: https://www.uzis.cz/res/f/008281/nzis-rep-2019-e04personalni-kapacity-odmenovani-2018.pdf

17. Ivanová K, Nakládalová M, Vévoda J (2012). Pracovní satisfakce všeobecných sester v ČR podle hodnotových distancí. Pracovní lékařství 64(4): 157-163.

18. Lee X, Yang B, Li W (2017). The influence factors of job satisfaction and its relationship with turnover intention: Taking early-career employees as an example. Anales de Psicología 33(3): 697-707. DOI: 10.6018/analesps.33.3.238551.

19. Lu H, Zhao $Y$, While AE (2019). Job satisfaction among hospital nurses: A literature review. Int J Nurs Stud 94: 21-31. DOI: 10.1016/j.ijnurstu.2019.01.011.

20. Masum AKM, Azad MAK, Hoque KE, Beh L-S, Wanke P, Arslan Ö (2016). Job satisfaction and intention to quit: an empirical analysis of nurses in Turkey. PeerJ 4: e1896. DOI: $10.7717 /$ peerj.1896.

21. MoH CR [Ministry of Health of the Czech Republic] (2009). Věstník Ministerstva zdravotnictví České republiky, částka 6: 40-42. [online] [cit. 2021-01-04]. Available from: https:// 
www.mzcr.cz/wp-content/uploads/wepub/3628/36956/ V\%C4\%9Bstn\%C3\%ADk\%20MZ\%20\%C4\%8CR\%206-2009.pdf

22. Nakládalová M, Vévoda J, Ivanová K, Marečková J (2011). Pracovní spokojenost všeobecných sester na lůžkových odděleních nemocnic. Pracovní lékařství 63(1): 18-23.

23. Simon M, Müller BH, Hasselhorn HM (2010). Leaving the organization or the profession - a multilevel analysis of nurses' intentions. J Adv Nurs 66(3): 616-626. DOI: 10.1111/j.13652648.2009.05204.x.
24. Smith KV, Godfrey NS (2002). Being a good nurse and doing the right thing: a qualitative study. Nurs Ethics 9(3): 301-312. DOI: 10.1191/0969733002ne512oa.

25. Spevan M, Kvas A, Bošković S (2020). Job satisfaction of nurses in Croatia, Slovenia and Serbia: a cross-sectional study. Cent Eur J Nurs Midw 11(4): 154-162. DOI: 10.15452/ CEJNM.2020.11.0027. 